\title{
ON THE INTERPRETATION OF JOHN SCYLITZES' EVIDENCE ABOUT ARCHONTES OF RHOS, AM 6544 (1036 AD)
}

\author{
Alexandr A. Romensky \\ State Museum-Preserve "Tauric Chersonesos", Sevastopol, Russian Federation
}

\begin{abstract}
Introduction. The article discusses the information of John Scylitzes about political changes in Rus on the eve of 1036. Methods. The comparison of the texts of different written traditions is carried out. The testimony of the "Synopsis Historion" by John Scylitzes is analyzed in the context of Russian Primary Chronicles data and other sources. Analysis. The chronicle of John Scylitzes contains a message about the death of the "archontes of Rhos" Nesisthlavos and Ierosthlavos, and election in their place their relative Zinisthlavos. These persons are traditionally identified with Russian princes Mstislav of Tmutarakan, Yaroslav the Wise and Iziaslav Yaroslavich. The researchers found chronological discrepancies in this evidence which were explained by the usage of different accounts in the chronicle. It seems that John Scylitzes' narration relied on Byzantine documents only and reproduced the events faithfully. His mistake was not in chronology but in explaining the reasons for the absence of Kievan prince during the siege of the city by Pechenegs in 1036. Results. As the study shows, the information of John Scylitzes does not contain any chronological contradictions and describes a reliable political situation. While the elder prince Yaroslav was in Novgorod, the Kievan veche elected his son Iziaslav who was a prince of Turov to rule in the city. The defeat of the Pechenegs after prince Yaroslav's return fits in the context of the Rus-Byzantine military alliance.

Key words: John Scylitzes, Byzantine narrative sources, Yaroslav the Wise, Iziaslav of Kiev, Pechenegs, princely power in Rus.

Citation. Romensky A.A. On the Interpretation of John Scylitzes' Evidence About Archontes of Rhos, AM 6544 (1036 AD). Vestnik Volgogradskogo gosudarstvennogo universiteta. Seriya 4. Istoriya. Regionovedenie. Mezhdunarodnye otnosheniya [Science Journal of Volgograd State University. History. Area Studies. International Relations], 2020, vol. 25, no. 6, pp. 44-55. (in Russian). DOI: https://doi.org/10.15688/jvolsu4.2020.6.3
\end{abstract}

\section{К ИНТЕРПРЕТАЦИИ ИЗВЕСТИЯ ИОАННА СКИЛИЦЫ ОБ АРХОНТАХ РУСИ ПОД 6544 (1036) ГОДОМ}

\author{
Александр Александрович Роменский \\ Государственный музей-заповедник «Херсонес Таврический», г. Севастополь, Российская Федерация
}

Аннотация. В статье рассматривается свидетельство хроники Иоанна Скилицы о трех архонтах Руси под 1036 годом. Традиционно их отождествляют с князьями Мстиславом и Ярославом Владимировичами, а также с сыном последнего Изяславом Ярославичем. Эта версия видится более вероятной, чем предположекнязя во время осады города печенегами. Его известие не противоречит контексту политических событий на негов с Византией в условиях действующего союза держав.

Ключевые слова: Иоанн Скилица, византийские нарративные источники, Ярослав Мудрый, Изяслав Ярославич, печенеги, княжеская власть на Руси. 
Цитирование. Роменский А. А. К интерпретации известия Иоанна Скилицы об архонтах Руси под 6544 (1036) годом // Вестник Волгоградского государственного университета. Серия 4, История. Регионоведение. Международные отношения. - 2020. - Т. 25, № 6. - С. 44-55. - DOI: https://doi.org/10.15688/jvolsu4.2020.6.3

Введение. Сведения византийских нарративных источников о Руси давно привлекают внимание исследователей, но, несмотря на появление в последнее время ценных справочных пособий и обобщающих работ [3; 12, с. 69-160], информационный потенциал этих памятников все еще не исчерпан. Одной из наиболее содержательных фактографически является хроника Иоанна Скилицы, охватывающая изложение основных событий византийской истории с 811 по 1057 год. Достоверных биографических данных об авторе немного: выходец из Фракисийской фемы, он занимал должности великого друнгария виглы и эпарха Константинополя с титулами протопроедра, впоследствии - куропалата при дворе Алексея I Комнина [59, S. 81-83; 49, p. 80-89; 53, p. IX-X]. Не больше ясности и в вопросе об источниках труда хрониста и методах его работы. Если в описании событий за IX - первую половину X в. Скилица в целом следует изложению хроник семейства Симеона Логофета, Генесия и Продолжателя Феофана, то в дальнейшем опирается на утраченные источники [49, р. 92-99; 52, р. XIIXVI; 53, p. XIX-XXII] ${ }^{1}$. Представление о Скилице как о компиляторе, механически воспроизводившем тексты предшественников, уступило место признанию того, что он нередко творчески переосмысливал имевшийся в его распоряжении материал. Вероятно, текст «Обозрения историй» был изначально расположен по тематическому принципу, лишь позже получив хронологическую организацию [49, p. $100 ; 62$, p. 220; 38, с. 60]. Иоанн Скилица не уделяет много внимания событиям на севере византийской ойкумены, упоминая о варварском народе Рос (о 'Р $\tilde{\omega} \varsigma)$ и его архонтах лишь в том случае, когда отношения с ними напрямую затрагивают интересы империи и правящих самодержцев ${ }^{2}$. Тем более интересны уникальные данные византийского автора о Руси, которые не находят подтверждения в других источниках. Одно из таких сообщений посвящено политической ситуации, сложившейся в 1036 году. Целесообразно рассмотреть свидетельство Скилицы в комплексе с другими данными и попытаться верифицировать его информацию.

Методы. Для реконструкции политической истории Руси и обстоятельств осады Киева печенегами в 1036 г. в исследовании используется метод сравнения текстов различных письменных традиций. Сообщение «Обозрения историй» Иоанна Скилицы анализируется в контексте известий Начальной летописи и других древнерусских источников (запись Остромирова Евангелия, перечень князей в Новгородской первой летописи (далее НПЛ)), что позволяет охарактеризовать взаимоотношения князей династии Рюриковичей в рамках сложившейся системы родового совладения, уточнить особенности баланса сил в рамках «дуумвирата» Ярослава и Мстислава Владимировичей, проследить начальный этап деятельности князя Изяслава Ярославича. Ключевой методологической предпосылкой представляется понимание нарратива как сложной семиотической системы, выступающего как динамический генератор смыслов [23].

Анализ. Текст «Обозрения историй» под 6544 г. состоит из сгруппированных хронологически записей о событиях в Византии и на ее границах, изложенных в характерном для хрониста стиле кратких обобщений. Обратимся непосредственно к источнику: Т $\tilde{\omega} \delta \grave{\varepsilon}$ , $\varsigma \varphi \mu \delta$ '

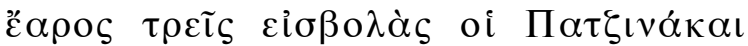

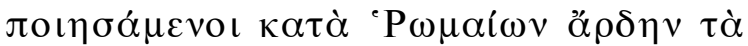

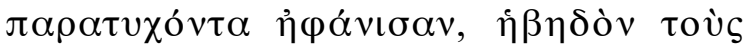

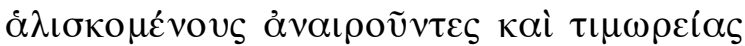

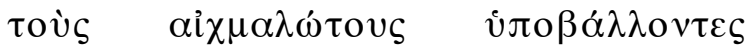

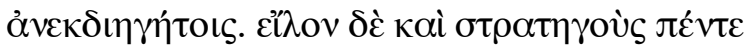

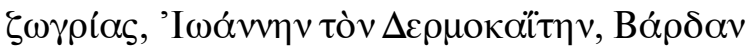

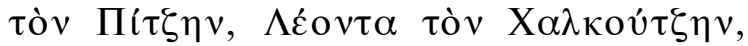

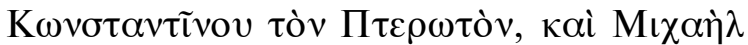

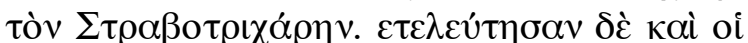

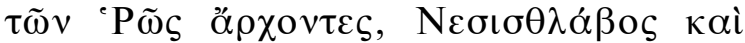

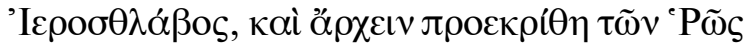

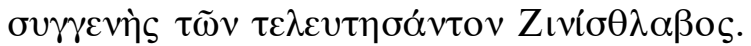

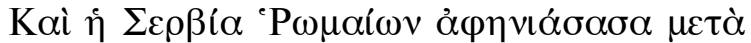

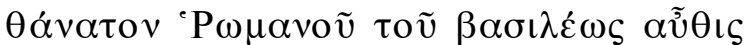

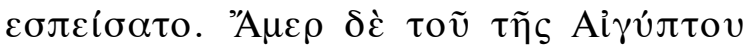




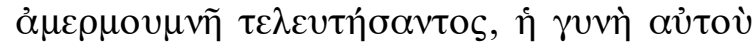
X

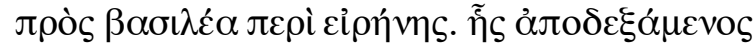

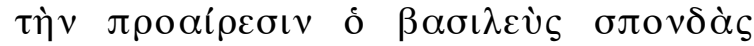

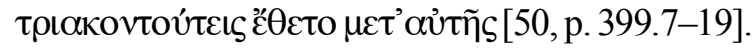
(«Весной четвертого индикта 6544 г. печенеги предприняли три набега против ромеев, уничтожая все встреченное на своем пути, убивая всех взрослых мужчин, подвергая пленных невыразимым карам. Были захвачены в плен пять стратигов: Иоанн Дермокаит, Варда Пица, Лев Халкуци, Константин Птерот и Михаил Стравотрихарис. Скончались и архонты Руси, Несислав и Иерослав, и был избран править родственник умерших, Зинислав. И Сербия, взбунтовавшаяся против ромеев после смерти василевса Романа [Аргира], снова заключила мирный договор. После смерти Амра, амермумна Египта, его женахристианка отправила послов вместе с сыном для заключения мира. Одобряя ее намерение, василевс заключил с ней соглашение на тридцать лет»).

Итак, согласно Скилице, смена власти на Руси произошла в промежутке между нападениями печенегов на Романию весной 1036 г. и смертью Фатимидского халифа Абуль Хасана Али ибн Мансура аз-Захир Биллаха, случившейся 13 июня того же года [53, p. 376 , note 34]. Печенежское нашествие 1036 г. продолжило череду разрушительных набегов степняков, атаковавших имперские границы в $1027,1032,1034-1035$ гг. [1, с. 112-114]. Хронология византийского хрониста может содержать неточности (согласно мусульманским источникам, заключение мирного соглашения ромеев с Фатимидами произошло в 427 г. хиджры $(1035 / 1036$ гг.)) [44, S. 107, А. 192], но в целом его информация достоверна и соответствует контексту происходивших событий. Разрушение печенегами ряда пограничных крепостей в Добрудже и Северо-Восточной Болгарии прослеживается и по археологическим источникам, нумизматический материал (анонимные фоллисы классов А-2 и В) позволяет датировать слой горения тридцатыми годами XI в. ${ }^{3}$, что соотносится с данными нарративов [43, p. 48-49; 1, с. 111-114].

Идентификация первых двух архонтов с представителями династии Рюриковичей не вызывает сомнений у большинства исследо- вателей: под именем «Несислава» у византийского автора фигурирует, вероятнее всего, Мстислав Владимирович, князь тмутараканский и черниговский, взявший под контроль левобережную часть «Русьской земли» после соглашения 1026 года. Примечательно, что на печати из Белгорода сохранился близкий вариант греческой транскрипции имени -

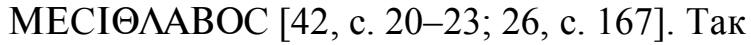
же бесспорно узнается и имя его брата Ярослава, княжившего в Киеве и Новгороде [11, с. 25]. Третий персонаж хроники - «Зинислав»- вероятнее всего, Изяслав Ярославич, преемник Ярослава Мудрого на киевском престоле [53, p. 376, note 33]; иногда его отождествляли со Станиславом смоленским (предполагая путаницу в источнике [41, с. 89-90; 33, с. 918-919]) либо с сыном Мстислава, Евстафием, скончавшимся раньше отца, в 1034 г. $[24$, c. 79]. Альтернативную интерпретацию предложил Дж. Шепард, согласно которому в тексте Скилицы сообщается о предводителях наемников на византийской военной службе. По мнению исследователя, эта информация противоречит как хронологии, так и внутриполитическому контексту событий на Руси. Он также отмечает, что термин «архонт» часто применялся в отношении военных чинов,

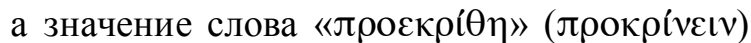
не соотносится с древнерусскими традициями наследования власти и может относиться к назначению командира наемного отряда; вероятно, предводители «росов» были убиты печенегами, так же как и упоминаемые выше пять плененных стратигов [60, p. 212-215].

По нашему мнению, свидетельство Скилицы вполне может быть согласовано с политическими обстоятельствами, сложившимися на Руси. Византийский автор не сообщает о гибели взятых в плен византийских военачальников, следовательно, прямо связывать с этим событием смерть двух «росских» архонтов нет оснований. Избрание их «родственника» Зинислава не выглядит уникальным случаем в контексте имеющихся сведений о роли веча на Руси, нередко определяющей исход политической борьбы в условиях кризисных ситуаций.

Более проблематично объяснение хронологического несоответствия в тексте византийского хрониста. Согласно сведениям На- 
чальной летописи, Мстислав Владимирович действительно умер в 1036 г., что позволило его брату Ярославу стать «самовластцем» «Русьской земли». Смерть самого «кагана» Ярослава случилась много позже, 20 февраля 1054 г. [16, стб. 150; 7, с. 39-41], и после этого ему наследовал старший из оставшихся сыновей, Изяслав Ярославич. Ошибку Скилицы объясняли использованием двух различных анналистических записей, информацию из которых он некритически скомпилировал [24, c. 78-80]. Второй вариант интерпретации сводился к тому, что хронист поменял местами имена упоминавшихся в его источнике правителей [41, с. 89-90].

Вопрос о том, откуда Иоанн Фракисийский черпал сведения о князьях далекой Руси, остается спорным. На наш взгляд, использование им гипотетических анналистических записей о смерти князей маловероятно. Для того чтобы навести справки о ком-то из чужеземных архонтов, автору вовсе не было нужды обращаться к историческим трудам. Информацию можно было позаимствовать из документов императорских ведомств, например архивов логофесии дрома, к которым Скилица, как высокопоставленный чиновник, безусловно, мог иметь доступ ${ }^{4}$. Следует отметить, что в столицу империи регулярно поступали донесения из приграничных фем, в частности, стратиг Херсона чаще всего сообщал в Константинополь о действиях печенегов и «тавроскифов» ${ }^{5}$. Актуальные сведения могли собирать византийские дипломаты-апокрисиарии или императорские порученцы - «василики», отправляемые к варварам. Видимо, они известили вышестоящих функционеров об изменениях среди правящей верхушки Руси, что было важно учитывать при планировании дипломатических и военных мероприятий.

Представляется, что свидетельство «Обозрения историй» вовсе не содержит разительных хронологических противоречий с другими источниками. Информатор византийского хрониста не ошибался в датировке событий, он лишь превратно истолковал факт отсутствия в Киеве князя Ярослава во время осады города. Для обоснования нашего предположения следует внимательнее присмотреться к политической истории Руси второй четверти XI века.
Масштабная усобица между сыновьями почившего в 1015 г. Владимира Святого заканчивается лишь в 1026 г. достижением компромисса между двумя сильнейшими князьями. Условия договора фактически продиктовал Мстислав Владимирович после неудачной для Ярослава Лиственской битвы 1024 г., в ходе которой его новгородско-варяжское войско потерпело поражение от хазар, касогов и северян. Став хозяином положения, Мстислав тем не менее уступил Киев старшему брату, поскольку не пользовался поддержкой среди жителей города («не приғаша єго Къгане») [20, стб. 147; 16, стб. 135]. Однако осторожный Ярослав не спешил к отчему столу, оставаясь на севере владений, в Новгороде. Все это время князь в Киеве фактически отсутствовал, и важнейший центр «Русьской земли» управлялся «мужами Ярославлими» [20, стб. 149; 16, стб. 136]. В том же 1024 г., по сообщению летописи, родился второй сын Ярослава, Изяслав. Лишь два года спустя братья встречаются в Городце, уславливаются о разделе Руси по Днепру и начинают «жити мирно и в братолюбьи» [20, стб. 149; 16, стб. 137], что соответствовало принципам классического родового совладения [27, с. 43-44]. Иногда братья предпринимают совместные военные экспедиции: так, они соединенными силами отстояли Червенские города, вмешавшись в ход внутренних распрей в Польше [20, стб. 150, 16 , стб. 137] ${ }^{6}$. Однако черниговский и тмутараканский князь, по-видимому, все же оставался самым влиятельным игроком в этом «дуумвирате», что не могло не вызывать ревности на правом берегу Днепра [37, с. 151]. Лаконичные известия летописи посвящены в основном деятельности Ярослава Владимировича, но создается впечатление, что он попрежнему уделял больше внимания делам на севере и западе. Лишь внезапная смерть Мстислава на охоте изменила сложившийся баланс сил, позволив его недавнему оппоненту сконцентрировать в своих руках «власть его всю» [20, стб. 150].

Показательно, что после смерти брата Ярослав в первую очередь спешит в остававшийся его главной опорой Новгород. Он оставляет старшего сына Владимира на новгородском столе и выдвигает на епископскую кафедру Луку Жидяту ${ }^{7}$. Именно в Новгоро- 
де князь и получает весть об осаде Киева печенегами, что заставляет его собирать войска. Путь войска из Новгорода до Киева с преодолением волока занимал как минимум месяц [22, с. 244]. В это время старейший стольный город Руси находился в печенежской осаде.

Ситуация для осажденных усугублялась отсутствием представителей княжеского рода, которые могли бы осуществить военное и политическое руководство. Авторитет «княжеских мужей»-посадников, достаточный для выполнения управленческих функций в мирное время, не был сравним с властью Рюриковичей, которая имела для современников сакральное символическое значение [36, с. 53-56]. Именно князь на Руси инициировал начало военных действий и санкционировал заключение мирных соглашений: так, в ходе карательной экспедиции против древлян малолетний Святослав первым бросил копье, упавшее под ноги коню, и лишь после этого жеста его дружина переходит к активным действиям [20, стб. 58; 16, стб. 46]. В условиях вакуума власти в городе неизбежно усиливалось значение веча, которое нередко определяло исход политического противоборства. Так, в частности, случилось в 1068 г., когда отказ Изяслава предоставить киевлянам оружие для борьбы с половцами привел к его свержению и вокняжению заточенного в «поруб» полоцкого князя Всеслава Брячиславича [20, стб. 170$172 ; 16$, стб. 160]. Именно под давлением киевского веча к власти в 1113 г. приходит Владимир Мономах $\left[16\right.$, стб. 275-276] ${ }^{8}$. Свидетельство Скилицы об избрании родственника умерших архонтов на их место, озадачившее Дж. Шепарда [60, p. 215], позволяет утверждать, что вопрос о князе в 1036 г. также решался на вече. Но кого могли избрать киевляне на стол «штенъ и дњденъ»? Старейший из оставшихся представителей династии Ярослав вместе со старшим сыном Владимиром находились в Новгороде. Единственной теоретически возможной представляется кандидатура Изяслава Ярославича.

Двенадцатилетний возраст подростка не являлся препятствием для выполнения княжеских обязанностей. «Пути и ловы» Мономаха, по словам его «Поучения», начались с тринадцати лет [20, стб. 247]; прадед Изяс- лава, Святослав Игоревич, ребенком участвовал в сражениях и, если верить свидетельству Константина Багрянородного, занимал новгородский стол в младенчестве, еще при жизни отца [19, с. 44]. Разумеется, выполнение реальных административных и военных функций при малолетнем княжиче возлагалось на воевод-«кормильцев» из числа наиболее доверенных и близких лиц $[9$, с. 50].

Источники не позволяют с определенностью проследить становление политической карьеры Изяслава Ярославича. Упоминая о распределении столов по «ряду» Ярослава Мудрого, Лаврентьевская летопись и близкие к ней списки умалчивают о месте его княжения, тогда как в Ипатьевском и Хлебниковском списках содержится запись о его пребывании в Турове [20, стб. 161; 16, стб. 149-150]. Специалисты полагают, что после кончины старшего брата Владимира в 1052 г. именно Изяславу достался важнейший новгородский стол, обладатели которого традиционно претендовали и на киевское княжение $[27$, с. 83 ; 6 , с. 306]. Основание для этого содержится в записи диакона Григория в Остромировом Евангелии (1057 г.): «...ИзАславоу же кънАзоу тогда пръдрьжАщоу объ власти и о(т)ца своего Іирослава. и брата своего Володимира. самъ же Изяславъ къндзь . правлгааше столъ о(т)ца своего Іирослава Кыєве. А брата своего столь поржчи правити близокоу своемоу Остромироу Нов ‘ город'ъ» [30, с. 588]. Но свидетельство этого источника, как и перечня новгородских князей в НПЛмл [29, с. 469], говорит о распределении княжений уже после кончины Ярослава Мудрого. К этому времени давно возмужавший княжич, несомненно, должен был привлекаться к управлению и до смерти старшего брата. Возможно, именно близкий к Киеву Туров стал его первой княжеской резиденцией (что и зафиксировал протограф Ипатьевского и Хлебниковского списков). Нет оснований предполагать нарушение сложившейся традиции в случае с Изяславом. Видимо, его приобщение к политической деятельности, как и в случае с другими сверстниками, началось уже в подростковом возрасте. Таким образом, нет ничего невероятного в том, что именно к Изяславу апеллировало киевское вече во время осады города печенегами, избрав его своим князем в условиях 
смерти Мстислава и отсутствия Ярослава. Источник Скилицы довольно точно передал эту информацию, ошибочно истолковав лишь причины отсутствия Ярослава Владимировича в Киеве.

Возвратившись в Киев с варягами и новгородцами, Ярослав с большим трудом отразил окруживших город степняков. По свидетельству Повести временных лет, решающая схватка произошла «вн' града», на месте будущего митрополичьего собора Св. Софии, после чего «побьгша Печен'зи разно» [20, стб. 151; 16, стб. 139]. Впечатляющая картина полного разгрома печенегов, созданная летописцем с использованием характерной для него риторики погибели врагов «до сего дни», едва ли полностью соответствовала действительности. В дальнейшем кочевники устремляются на Балканы, не раз опустошая византийскую территорию. Не исчезли они и в степях Восточной Европы, взаимодействуя с другими тюркскими этносами, пришедшими им «на смену», - торками и половцами и даже поступая на службу к русским князьям. Только василевсы из династии Комнинов, Алексей I и его сын Иоанн, смогли положить конец этой угрозе для империи ромеев [32, c. $99-100 ; 45$, p. 80].

Хронологическая и тематическая последовательность изложения Скилицы, согласно которой смена архонтов на Руси последовала непосредственно после нападения печенегов на Византию и пленения пяти стратигов представителей известных родов византийской военной аристократии, создает впечатление взаимосвязанности событий на границах империи и в Восточной Европе. Координацию действий, направленных против номадов, между киевским князем и правительством василевса Михаила IV нельзя категорически исключать, поскольку в эти годы продолжал существовать военный и политический альянс двух держав, оформившийся в основных чертах к концу X века. Мелкие инциденты и конфликтные ситуации, как, например, случай с отрядом наемников некоего Хрисохира, не меняли приверженности обеих сторон к сотрудничеству [50, р. 367; 22, с. 223-227; 39]. Примечательно, что именно после победы над печенегами князь Ярослав смог завершить грандиозный проект строительства митропо- личьего кафедрала - собора Св. Софии - с помощью византийских мастеров ${ }^{9}$. Тогда же, вероятно, были окончательно согласованы вопросы статуса киевской митрополии, остававшейся зависимой от Константинополя, который тем не менее учитывал предпочтения светской власти на Руси, не раз склоняясь к компромиссу с ее архонтами [8, с. 149-151]. Даже последняя масштабная война «росов» и ромеев в 1043 г. не изменила в длительной перспективе общих тенденций в их взаимоотношениях, увенчавшись вскоре новым мирным соглашением [22, с. 274-276].

Выводы. Как представляется, свидетельство Иоанна Скилицы о смене архонтов на Руси в 1036 г. не содержит существенных хронологических противоречий. Информатор византийского хрониста в целом достоверно охарактеризовал политический расклад сил, сложившийся в ходе осады Киева печенегами, допустив ошибку лишь в трактовке причин отсутствия Ярослава. В условиях отъезда князя в стольном городе решающая роль, видимо, перешла к вечу, которое предложило киевский стол подростку Изяславу Ярославичу. Начало политической карьеры последнего, вероятно, связано с княжением в близком к Киеву Турове. Малолетство Изяслава не исключало его участия в функциях управления и военных действиях при поддержке «кормильцев» из числа опытных воевод. Кризис был разрешен после возвращения Ярослава Владимировича с войском из Новгорода и успешного отражения печенегов. Победа киевского князя над печенегами, последовавшая после их вторжений на территорию Византии, вписывается в контекст военного сотрудничества двух государств.

\section{ПРИМЕЧАНИЯ}

1 Попытки реконструировать источники «Обозрения историй» остаются в рамках недостаточно обоснованных гипотез. Это касается и так называемой «Истории Фок», из которой, по мнению исследователей, заимствованы многие общие сведения Льва Диакона и Иоанна Скилицы [35, c. $145-146 ; 17$, с. $115-116 ; 54$, р. $253 ; 63$, p. $32 ; 53$, p. XVIII-XIX], и выдвинутого в противовес этому мнения о лояльном к роду Склиров источнике [49, p. 272]. В описании правления Василия II, как полагают специалисты, автор мог использовать несох- 
ранившийся исторический труд Феодора Севастийского [4, с. 67-68; 2, с. 138-139], однако определение его конкретных фрагментов (например, среди известий об апостасии Варды Фоки в «Чудесах св. Евгения Трапезундского), как представляется, трудно аргументировать. См.: [57; 49, p. 96-97].

2 О терминологии византийских источников в применении к князьям Руси см.: [61; 58, p. 424-425].

${ }^{3}$ Специалисты не пришли к единому мнению относительно классификации и хронологии анонимных фоллисов. См.: [55, p. 586-600; 46, p. 634 639; 47, p. 204-209; 51, p. 37-39; 1, c. 112].

${ }^{4}$ Об эволюции должности логофета дрома и его функциях см.: [48, p. 31-70; 25].

5 Известно, что патрикий и стратиг Херсона Иоанн Вога сообщал Патриарху Николаю Мистику о потенциально опасных контактах болгар и печенегов, другой его коллега прислал в Константинополь донесение о готовящемся нападении Руси в 941 г. См.: [56, p. 58; 34, c. 1477-1480; 14, с. 414-415; 40$, c. $15-17]$.

${ }^{6}$ Военные действия Мстислава и Ярослава в Польше, очевидно, были согласованы с императором Священной Римской империи Конрадом II, начавшим тогда же войну против Мешко II. См.: [10, с. 35-37; 18, с. 260-262; 28, с. 613-614]. Поздняя Никоновская летопись упоминает о походе Ярослава «на ясы», который, в случае его реальности, мог быть предпринят только для поддержки притязаний Мстислава [31, с. 81]; но это известие едва ли заключает в себе нечто большее, чем вымысел книжника XVI века.

7 Принимаемая некоторыми историками версия об Илье, упоминаемом в списке новгородских князей НПЛмл и летописи Авраамки [29, с. 471; 21, c. 313], как самом старшем из сыновей Ярослава видится несостоятельной. Более вероятно предположение о тождестве Ильи и Владимира Ярославича: старший из Ярославичей принял крестильное имя в честь великого ветхозаветного пророка и святого покровителя василевсов правящей в Византии Македонской династии [18, с. $67 ; 24$, с. 77, примеч. 126].

${ }^{8}$ Исследователи спорят о легитимности вокняжения Владимира Всеволодовича в 1113 году. А.В. Назаренко полагает, что Любечский съезд исключил детей Святослава Ярославича, воспринимавшегося как узурпатор, из числа отчичей Киева, на который, таким образом, могли претендовать только сыновья Изяслава и Всеволода [27, с. 93-94]. Несмотря на наличие аргументов в пользу этой интерпретации, она остается небезупречной. Если Святославичи действительно не имели прав на Киев, то чем было вызвано промедление Мономаха, решившегося войти в город лишь после двукратного требования веча? Едва ли такое поведение ос- торожного политика можно объяснить одной лишь скорбью по умершему Святополку Изяславичу. «Болшие и нарочитые» мужи, составлявшие, согласно «Сказанию о святых Борисе и Глебе», партию сторонников Мономаха на вече [15, с. 64], вовсе не были уверены в его согласии на принятие власти, и чтобы его добиться, им пришлось прибегнуть к давлению.

9 Проблема времени строительства собора Св. Софии в Киеве остается крайне дискуссионной. В последнее время к традиционной полемике сторонников «ранней» и «поздней» дат 1017 и 1037 гг., содержащихся в НПЛ и Повести временных лет соответственно, прибавилась контроверсионная гипотеза о закладке кафедрала уже князем Владимиром. Важно отметить, что достоверный terminus ante quem освящения храма представляет собой греческое граффито с датой 1038 год. В архитектурном плане собор отражает черты византийского зодчества второй четверти ХІ века. См.: [13, с. 493-494; 5].

\section{СПИСОК ЛИТЕРАТУРЫ}

1. Атанасов, Г. Г. Анонимные византийские фоллисы класса В и нашествие печенегов в Добруджу 1036 г. / Г. Г. Атанасов // Stratum Plus. Apхеология и культурная антропология. - 1999. - № 6. С. 111-122.

2. Бибиков, М. В. Историческая литература Византии / М. В. Бибиков. - СПб. : Алетейя, 1998. $316 \mathrm{c}$.

3. Бибиков, М. В. Byzantinorossica : Свод византийских свидетельств о Руси. В 2 т. Т. 1 / М. В. Бибиков. - М. : Яз. слав. культуры : Рукоп. памятники Древ. Руси, 2004. - 736 с.

4. Васильевский, В. Г. Русско-византийские отрывки. ІІ. К истории 976-986 гг. / В. Г. Васильевский // Труды В.Г. Васильевского. В 4 т. Т. 2. - СПб. : Тип. Императ. Акад. наук, 1909.- С. 56-124.

5. Виноградов, А. Ю. Святая София Киевская в контексте византийской архитектуры второй четверти ХІ в. / А. Ю. Виноградов // Храм і люди : збірка статей до 90-річчя з дня народження С.О. Висоцького / відп. ред. Є. І. Архіпова, Г. Ю. Івакін. - Київ : Інститут археології НАН України, Національний заповідник «Софія Київська», 2013. - С. 66-80.

6. Войтович, Л. В. Княжа доба на Русі: портрети еліти / Л. В. Войтович. - Біла Церква : Видавець Олександр Пшонківський, 2006. - 784 с.

7. Высоцкий, С. А. Дрвнерусские надписи Софии Киевской. Вып. 1. XI-XIV вв. / С. А. Высоцкий. - К. : Наукова думка, 1966. - 240 с.

8. Гайденко, П. И. Становление высшего церковного управления в Киевской Руси : дис. ... д-ра 
ист. наук / Гайденко Павел Иванович . - Екатеринбург, 2011. -459 с.

9. Гарданов, В. К. «Кормильство» в Древней Руси / В. К. Гарданов // Советская этнография. 1959. - № 6. - С. 43-59.

10. Головко, А. Б. Древняя Русь и Польша в политических взаимоотношениях $\mathrm{X}$ - первой трети ХІІІ вв. / А. Б. Головко. - К. : Наукова думка, 1988. $136 \mathrm{c}$.

11. Грушевський, М. С. Історія України-Руси. Т. 2. ХІ-XIII вік / М. С. Грушевський. - Львів : 3 друкарні Наукового товариства імени Шевченка, 1905. $633 \mathrm{c}$.

12. Древняя Русь в свете зарубежных источников : учеб. пособие / М. В. Бибиков [и др.] ; под ред. Е. А. Мельниковой. - М. : Логос, 2003. - 608 с.

13. Евдокимова, А. А. Корпус греческих граффити Софии Киевской на фресках первого этажа / А. А. Евдокимова // Древнейшие государства Восточной Европы. Рюриковичи и российская государственность / отв. ред. М. В. Бибиков, Е. А. Мельникова, В. Д. Назаров. - М. : Индрик, 2008. - С. 465-518.

14. Житие Василия Нового в древнейшем славянском переводе. Т. 1. Исследования. Тексты / изд. подгот. Т. В. Пентковская, Л. И. Щеголева, С. А. Иванов. - М. : Яз. слав. культуры, 2018. - 779 с.

15. Жития святых мучеников Бориса и Глеба и службы им / пригот. к печати Д. И. Абрамович. М. : Худож. лит., 1980. - 704 с. - (Памятники древнерусской литературы : в 12 вып. / сост. и общ. ред. Л. А. Дмитриева, Д. С. Лихачева ; вып. 2 ).

16. Ипатьевская летопись. - СПб. : Тип. М.А. Александрова, 1908. - XVI с., 938 стб., 87, IV c. - (Полное собрание русских летописей ; т. 2 / подгот. А. А. Шахматов).

17. Каждан, А. П. Из истории византийской хронографии Х в. / А. П. Каждан // Византийский временник. - 1961. - Т. 20. - С. 106-125.

18. Карпов, А. Ю. Ярослав Мудрый / А. Ю. Карпов. - М. : Молодая гвардия, 2001. - 583 с. - (Жизнь замечательных людей ; вып. 1008 (808)).

19. Константин Багрянородный. Об управлении империей. Текст, перевод, комментарий / под ред. Г. Г. Литаврина, А. П. Новосельцева. - М. : Наука, 1989. - 496 с.

20. Лаврентьевская летопись. - Л. : Изд-во АН CCCP, 1926. - VIII с., 579 стб. - (Полное собрание русских летописей ; т. 1 / под ред. Е. Ф. Карского).

21. Летописный сборник, именуемый летописью Авраамки. - СПб. : Тип. Ф. Еленского и К., 1889. - 319, 69 с. - (Полное собрание русских летописей ; т. 16 / подгот. А. Ф. Бычков, К. Н. БестужевРюмин).

22. Литаврин, Г. Г. Византия, Болгария, Древняя Русь (IX - начало XII вв.) / Г. Г. Литаврин. СПб. : Алетейя, 2000. - 415 с.
23. Лотман, Ю. М. К современному понятию текста // Статьи по семиотике культуры и искусства / Ю. М. Лотман. - СПб. : Акад. проект, 2002. - С. 79-83.

24. Михеев, С. М. «Святополкъ съде в Киевь по отци». Усобица 1015-1019 годов в древнерусских и скандинавских источниках / С. М. Михеев. М. : Ин-т славяноведения РАН, 2009. - 292 с. - (Славяно-германские исследования ; т. 4).

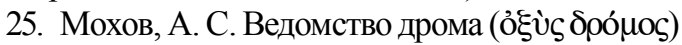
в X-XI вв. / А. С. Мохов // Византийский временник. - 2011. - Т. 70. - С. 25-36.

26. Назаренко, А. В. Немецкие латиноязычные источники IX-XI вв. Тексты, перевод, комментарий / А. В. Назаренко. - М. : Наука, 1993. - 240 с.

27. Назаренко, А. В. Древняя Русь и славяне / А. В. Назаренко. - М. : Рус. фонд содействия образованию и науке, 2009. - 528 с. - (Древнейшие государства Восточной Европы. 2007).

28. Назаренко, А. В. Достоверные годовые даты в раннем летописании и их значение для изучения древнерусской историографии / А. В. Назаренко // Зарождение историописания в обществах Древности и Средневековья / отв. ред. тома Д. Д. Беляев, Т. В. Гимон. - М. : Изд-во Ун-та Дмитрия Пожарского, 2016. - С. 593-654. - (Древнейшие государства Восточной Европы. 2013).

29. Новгородская первая летопись старшего и младшего изводов / под ред. А. Н. Насонова. - М. ; Л. : Изд-во АНСССР, 1950. - 640 с.

30. Остромирово Евангелие, 1056-1057 / предисл. А. Х. Востокова. - Факс. воспр. - Л. : Аврора, 1988. $-588 \mathrm{c}$.

31. Патриаршая или Никоновская летопись. М. : Наука, 1965. - 256 с. - (Полное собрание русских летописей ; т. 9 / подгот. А. Ф. Бычков).

32. Пріцак, О. Й. Печеніги / О. Й. Пріцак // Український історик. - 1970. - № 1-3. - С. 95-101.

33. Пріцак, О. Й. Походження Русі. Т. 2. Стародавні скандинавські саги і стара Скандинавія / О. Й. Пріцак.Київ : Обереги, 2003.- 1304 с.

34. Сорочан, С. Б. Византийский Херсон. Очерки истории и культуры. Ч. 1-2 / С. Б. Сорочан. Харьков : Майдан, 2005. - 1644 c.

35. Сюзюмов, М. Я. Об источниках Льва Диакона и Скилицы / М. Я. Сюзюмов // Византийское обозрение. - 1916. - Т. 2, вып. 1. - С. 106-166.

36. Толочко, О. П. До питання про сакральні чинники становлення князівської влади на Русі у IX-X ст. / О. П. Толочко // Археологія. - 1990. № $1 .-$ C. $51-63$.

37. Толочко, О. П., Толочко, П. П. Київська Русь / О. П. Толочко, П. П. Толочко. - К. : Альтернативи, 1998. $-352 \mathrm{c}$.

38. Филипчук, О. М. Перечитуючи Іоанна Скілицю: хто був Сфенг - брат Володимира Святого? / О. М. Филипчук // Історична панорама : 
збірник наукових статей Чернівецького національного університету. Спеціальність «Історія». - 2009. Вип. 8. - С. 58-70.

39. Филипчук, А. М. Русь и Византия в последние годы правления Василия II: Хризохир и его воины / А. М. Филипчук // Colloquia Russica. 2015. - Vol. 5. - C. 55-70.

40. Хапаев, В. В. Роль стратигов Херсона в осуществлении внешней политики Византийской империи в первой половине Х в. / В. В. Хапаев // Материалы по археологии и истории античного и средневекового Крыма. - 2013. - Вып. 5. C. 14-25.

41. Шахматов, А. А. Разыскания о древнейших русских летописных сводах / А. А. Шахматов. СПб. : Тип. М.А. Александрова, 1908. - 686 с.

42. Янин, В. Л. Актовые печати Древней Руси X-XV вв. В 2 т. Т. 1. Печати X- начала XIII в. / В. Л. Янин. - М. : Наука, 1970. - 326 с.

43. Diaconu, P. Les Petchénègues au Bas-Danube / P. Diaconu. - Bucarest : Éditions de l'Académie de la République socialiste de Roumanie, 1970. - 158 p. (Bibliotheca historica Romaniae ; vol. 27).

44. Felix, W. Byzanz und die islamische Welt im früheren 11. Jahrhundert/W. Felix. - Wien : Verlag der Österreichischen Akademie der Wissenschaften, 1981. $-236 \mathrm{~S}$.

45. Golden, P. B. Studies on the Peoples and Cultures of the Eurasian Steppes / P. B. Golden.Bucureşti ; Brăila : Editura Academiei Romane : Editura Istros a muzeului Brăilei, 2011. - 424 p.

46. Grierson, P. Catalogue of the Byzantine Coins in the Dumbarton Oaks Collection and in the Whittemore Collection. Vol. 3. Part 1/2 / P. Grierson.Washington, DC : Dumbarton Oaks Research Library and Collection, 1973. - X, 887 p., 70 pl.

47. Grierson, P. Byzantine Coins / P. Grierson.L. : Methuen and Co. ; Berkeley ; Los Angeles : University of California Press, 1982. - XIII, 411 p.

48. Guilland, R. Les logothèthes. Etudes sur l'histoire administrative de l'Empire byzantine / R. Guilland // Revue des études byzantines. 1971. - T. 29. - P. 5-115.

49. Holmes, C. Basil II and the Governance of Empire / C. Holmes. - N. Y. : Oxford University Press, 2005. - XIV, $625 \mathrm{p}$.

50. Ioannis Scylitzae Synopsis Historiarum / rec. I. Thurn. - Berolini : Walter de Gruyter, 1973. - LVI, 580 p. - (Corpus fontium historiae byzantinae; vol. 5).

51. Ivanišević, V. Interpretation and Dating of the Folles of Basil II and Constantine VIII - the Class A2 / V. Ivanišević // Зборник Радова византолошког института. - 1989. - Т. 27/28. - P. 19-42.

52. Jean Scylitzès. Empereurs de Constantinople / texte traduit par B. Flusin et annoté par J.-Cl. Cheynet. P. : Éditions P. Lethielleux, 2003. - XXX, 467 p.
53. John Skylitzes. A Synopsis of Byzantine History / transl. by J. Worthley; with introd. by J.-Cl. Cheynet, B. Flusin. - Cambridge : Cambridge University Psess, 2010. - XXXIII, $491 \mathrm{p}$.

54. Ljubarski, J. N. Nikephoros Phokas in Byzantine Historical Writings / J. N. Ljubarski // Byzantinoslavica. - 1993. - T. 54, Fasc. 2. - P. 245-253.

55. Morrisson, C. Catalogue des monnaies byzantines de la Bibliothèque nationale. T. 2 . Philippicus à Alexis III / Morrisson C. - P. : Bibliotheque Nationale, 1970. - 844 p.

56. Nicholas I, Patriarch of Constantinople. Letters / ed. by R. J. H. Jenkins, L. G. Westerink. Washington: Dumbarton Oaks Center for Byzantine Studies, 1973. - XXXVII, 631 p. - (Corpus fontium historiae byzantinae; vol. 6).

57. Panagiotakes, N. Fragments of a Lost Eleventh Century Byzantine Historical Work? / N. Panagiotakes // $\Phi ا \lambda \varepsilon ́ \lambda \lambda \eta v$ : Studies in Honour of Robert Browning / ed. C. N. Constantinides, N. M. Panagiotakes, E. Jeffreys, A. D. Angelou. - Venice : Istituto ellenico di studi bizantini e postbizantini di Venezia, 1996. - P. 321-357.

58. Poppe, A. O tytule wielkoksiążęcym na Rusi / A. Poppe // Przegląd Historyczny. - 1984. - T. 75/3. S. 423-439.

59. Seibt, W. Johannes Skylitzes. Zur Person des Chronisten / W. Seibt // Jahrbuch der Österreichischen Byzantinistik. - 1976. - Bd. 25. - S. 81-85.

60. Shepard, J. Byzantinorussica/J. Shepard// Revue des études byzantines. - 1975. - T. 33. - P. 211-225.

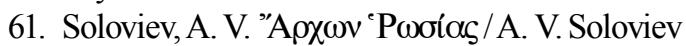
// Byzantion. - 1961. - T. 31. - P. 237-244.

62. Stephenson, P. Review: Catherine Holmes, "Basil II and the Governance of Empire (976-1025)" (Oxford, 2005) / P. Stephenson // Byzantinische Zeitschrift. - 2007. - Bd. 100/1. - P. 218-223.

63. The History of Leo the Deacon. Byzantine Military Expansion in the Tenth Century / introd., transl., and annot. by A.-M. Talbot, D. F. Sullivan with the assistance of G. T. Dennis and S. McGrath. Washington, DC : Dumbarton Oaks Research Library and Collection, 2005. - XIX, $264 \mathrm{p}$.

\section{REFERENCES}

1. Atanasov G. G. Anonimnye vizantiyskie follisy klassa B i nashestvie pechenegov v Dobrudzhu $1036 \mathrm{~g}$. [The Anonymous Byzantine Folles of the Class B and the Pechenegs' attack on Dobrudzha in 1036]. Stratum Plus. Arkheologiya i kulturnaya antropologiya [Stratum Plus. Archaeology and Cultural Anthropology], 1999, vol. 6, pp. 111-122.

2. Bibikov M. V. Istoricheskaya literatura Vizantii [Historical Literature of Byzantium]. St.-Petersburg, Aleteiia Publ., 1998. 316 p. 
3. Bibikov M. V. Byzantinorossica: Svod vizantiyskikh svidetelstv o Rusi. T. 1 [Corpus of Byzantine Testimonies about Rus']. Moscow, Yazyki slavyanskoy kultury Publ. ; Rukopisnye pamyatniki Drevney Rusi Publ., 2004. 736 p.

4. Vasilevskiy V. G. Russko-vizantiyskie otryvki. II. K istorii 976-986 gg. [Russian-Byzantine passages. II. To the history of 976-986]. Trudy V. G. Vasilevskogo [Proceedings of V. G. Vasilievsky]. T. 2. SaintPetersburg, Tipografiya Imperatorskoy Akademii nauk Publ., 1909. pp. 56-124.

5. Vinogradov A. Yu. Svyataya Sofiya Kievskaya v kontekste vizantiyskoy arkhitektury vtoroy chetverti XI v. [Hagia Sophia of Kiev in the context of Byzantine architecture of the second quarter of the $11^{\text {th }}$ century]. Arkhipova E. I., Ivakin G. Yu, ed. Khram i ludy: zbirka statei do 90-richchia $z$ dnia narodzhennia S. O. Vysotskogo [Temple and people: articles dedicated to the $90^{\text {th }}$ anniversary of S. O. Vysotsky]. Kyiv, Institut arkheologii NAN Ukraiiny, Natsionalnii zapovidnik «Sofiia Kiïvska» Publ., 2013. pp. 66-80.

6. Voitovych L. V. Kniazha doba na Rusi: portrety elity [PrincelyEra in Rus': Portraits of Elite]. Bila Tserkva, Oleksandr Pshonkivs'kii Publ., 2006. 784 p.

7. Vysotskiy S. A. Drvnerusskie nadpisi Sofii Kievskoy. Vol. 1. XI-XIV vv. [Ancient Rus' graffiti of St. Sophia Cathedral]. Kiev, Naukova dumka Publ., $1966.240 \mathrm{p}$.

8. Gaydenko P. I. Stanovlenie vysshego tserkovnogo upravleniya $v$ Kievskoy Rusi: diss. dokt. ... ist. nauk [The formation of the highest church administration in Kievan Rus. Dr. Hist. Sci. Diss.]. Ekaterinburg, 2011.459 p.

9. Gardanov V. K. «Kormilstvo» v Drevney Rusi ["Kormilstvo" in Ancient Rus']. Sovetskaya etnografiya [Soviet etnography], 1959, vol. 6, pp. 43-59.

10. Golovko A. B. Drevnyaya Rus i Polsha v politicheskikh vzaimootnosheniyakh $X$-pervoy treti $X I I I v v$. [Ancient Russia and Poland in political relations of the $10^{\text {th }}$ - first third of the $13^{\text {th }}$ centuries]. Kiev, Naukova dumka Publ., 1988. 136 p.

11. Grushevskiy M. S. Istoriya Ukraiiny-Rusi. T. 2. XI-XIII vik. [History of Ukraine-Rus'. Vol. 2. $11^{\text {th }}$ $13^{\text {th }}$ Centuries]. Lviv: Naukovogo tovaristva imeni Shevchenka Publ., 1905. 633 p.

12. Bibikov M. V., Glazyrina G. V., Dzhakson T. N., Melnikova E. A. et al., ed. Drevnyaya Rus v svete zarubezhnykh istochnikov: Uchebnoe posobie dlya studentov vuzov [Ancient Russia in the light of foreign sources : Textbook]. Moscow, Logos Publ., 2003. $608 \mathrm{p}$.

13. Evdokimova A. A. Korpus grecheskikh graffiti Sofii Kievskoy na freskakh pervogo etazha [Corps of Greek graffiti of Sophia of Kiev on the frescoes of the first floor]. Bibikov M. V., Melnikova E. A., Nazarov V. D., eds. Drevneyshie gosudarstva Vostochnoy Evropy.
Ryurikovichi i rossiyskaya gosudarstvennost [Ancient states of Eastern Europe. Rurikovichi and Russian statehood]. Moscow, Indrik Publ., 2008. pp. 465-518.

14. PentkovskayiaT. V., Shchegoleva L. I., IvanovS. A., eds. Zhitie Vasiliya Novogo $v$ drevneyshem slavyanskom perevode. T. 1. Issledovaniya. Teksty [The Life of Basil the New in the ancient Slavic translation. T. 1. Research. Texts]. Moscow, Yazyki slavyanskoy kultury Publ., 2018. 779 p.

15. Abramovich D. I., ed. Zhitiya svyatykh muchenikov Borisa i Gleba i sluzhby im [The lives of the holy martyrs Boris and Gleb and their services]. Dmitrieva L. A., Likhachev D. S., eds. Pamyatniki drevnerusskoy literatury. Vyp. 2 [Monuments of ancient Russian literature. Vol. 2]. Petrograd, Tiporgafiya Imperatorskoy Akademii Nauk Publ., 1916. XXXII, $204 \mathrm{p}$.

16. Ipatevskaya letopis [Ipatian Chronicle]. Shakhmatov A.A., ed. Polnoe sobranie russkikh letopisey [Full Collection of the Russian Chronicles]. T. 2. St.-Petersburg, M. Alexandrov Publ., 1908. XVI p., 938 col., 87 , IV p.

17. Kazhdan A. P. Iz istorii vizantiyskoy khronografii X v. [From the history of Byzantine chronography of the tenth century]. Vizantiiskii vremennik, 1961, vol. 20, pp. 106-125.

18. Karpov A. Yu. Yaroslav Mudryy [Iaroslav the Wise]. Moscow, Molodaya gvardiya Publ., 2001. 583 p. (Zhizn zamechatelnykh lyudei Vol. 1008 (808).

19. Litavrin G. G., Novoseltsev A. P., eds. Ob upravlenii imperiey. Tekst, perevod, kommentarii [The De administrando imperio. Text, translation and Comments]. Moscow, Nauka Publ., 1989. 496 p.

20. Lavrentevskaya letopis [Laurentian Chronicle]. Karskiy E. F., ed. Polnoe sobranie russkikh letopisey. T. 1. [Full Collection of Russian Chronicles. Vol. 1]. Leningrad, AN SSSR Publ., 1926. VIII p., 579 col.

21. Letopisnyy sbornik, imenuemyy letopisyu Avraamki [The Avraamka's Chronicle]. Bychkov A. F., Bestuzhev-Ryumin K. D., eds. Polnoe sobranie russkikh letopisey. T. 16 [Full Collection of Russian Chronicles. Vol. 16]. St.-Petersburg, Tipografiya F. Elenskogo I K. Publ., 1889. 319, 69 p.

22. Litavrin G. G. Vizantiya, Bolgariya, Drevnyaya Rus (IX - nachalo XII vv.) [Byzantium, Bulgaria and the Ancient Rus']. St.-Petersburg, Aleteii Publ., 2000. 415 p.

23. Lotman Yu. M. K sovremennomu ponyatiyu teksta [To the modern concept of the text]. Lotman Yu. M. Stati po semiotike kultury $i$ iskusstva [Articles on the semiotics of culture and art]. St.-Petersburg, Gumanitarnoe agenstvo "Akademicheskiy proekt" Publ., 2002. pp. 79-83.

24. Mikheev S. M. "Sviatopolk sede v Kieve po ottsi". Usobitsa 1015-1019 godov v drevnerusskikh i skandinavskikh istochnikakh [Sviatopolk owned 
Kiev after the Father. Strife of 1015-1019 in Old Russian and Scandinavian Sources]. Moscow, Institut slavyanovedeniya RAN Publ., 2009. 292 p. (Slavyanogermanskie issledovaniya. Vol. 4).

25. Mokhov A. S. Vedomstvo droma (oksys dromos) v X-XI vv. [The Department of the ỏ $\xi \dot{v} s$ $\delta \rho o ́ \mu \rho \varsigma$ in the $10^{\text {th }}-11^{\text {th }}$ Centuries]. Vizantiskii vremennik, 2011, vol. 70, pp. 25-36.

26. Nazarenko A. V. Nemetskie latinoyazychnye istochniki IX-XI vv. Teksty, perevod, kommentarii [German Latin-Sources of the $9^{\text {th }}-11^{\text {th }}$ centuries. Texts, Translation, Comment]. Moscow, Nauka Publ., 1993. $240 \mathrm{p}$.

27. Nazarenko A. V. Drevnyaya Rus $i$ slavyane [Ancient Russia and the Slavs]. Moscow, Russkiy fond sodeystviya obrazovaniyu i nauke Publ., 2009. 528 p. (Drevneishie gosudarstva Vostochnoy Evropy. 2007 g.).

28. Nazarenko A. V. Dostovernye godovye daty $\mathrm{v}$ rannem letopisanii i ikh znachenie dlya izucheniya drevnerusskoy istoriografii [Reliable annual dates in the early chronicles and their importance for the study of ancient Russian historiography]. Belyaev D D., Gimon T. V., eds. Drevneyshie gosudarstva Vostochnoy Evropy. 2013. Zarozhdenie istoriopisaniya $v$ obshchestvakh Drevnosti i Srednevekovya [Ancient States of Eastern Europe. 2013. The Origin of Historical Writing in the Societies of Antiquity and the Middle Ages]. Moscow, Izdatelstvo Universiteta Dmitriya Pozharskogo Publ., 2016. pp. 593-654.

29. Nasonov A. N., ed. Novgorodskaya pervaya letopis starshego i mladshego izvodov [Novgorod First Chronicle]. Moscow ; Leningrad, AN SSSR Publ., $1950.640 \mathrm{p}$.

30. Vostokov A. Kh., ed. Ostromirovo Evangelie, 1056-1957 : faksimilnoe vosproizvedenie [Ostromir Gospel, 1056-1957: facsimile reproduction]. Leningrad, Aurora Publ., 1988. 588 p.

31. Patriarshaya ili Nikonovskaya letopis [Nikonian Chronicle]. Bychkov A. F., ed. Polnoe sobranie russkikh letopisey. T. 9 [Full Collection of Russian Chronicles. Vol. 9]. Moscow, Nauka Publ., 1965. 256 p.

32. Pritsak O. I. Pechenigy [The Pechenegs]. Ukraiinskyi istoryk [Ukrainian Historian], 1970, vol. 1-3, pp. 95-101.

33. Pritsak O. I. Pokhodzhennia Rusi. T. 2. Starodavni skandinavs'ki sagi i stara Skandinaviia [The Origin of Rus. Ancient Scandinavian sagas and old Scandinavia]. Kyiv, Oberegy Publ., 2003. 1304 p.

34. Sorochan S. B. Vizantiyskiy Kherson. Ocherki istorii $i$ kultury. Chast 1-2 [Byzantine Cherson. Essays on History and Culture]. Vol. 1-2. Kharkov, Maidan Publ., 2005. 1644 p.

35. Syuzyumov M. Ya. Ob istochnikakh Lva Diakona i Skilitsy [About the Sources of Leo the Deacon and Scylitzes]. Vizantiyskoe obozrenie [Byzantine Review], 1916, vol. 2, no. 1, pp. 106-166.
36. Tolochko O. P. Do pytannia pro sakral'ni chinnyky stanovlennia kniazivs'koii vlady na Rusi u IX-X st. [On the question of the sacred factors of the formation of princely power in the $9^{\text {th }}-10^{\text {th }}$ centuries]. Arkheologiia [Archaeology], 1990, no 1, pp. 51-63.

37. Tolochko O. P., Tolochko P. P. Kyivska Rus [Kievan Rus']. Kyiv, Alternatyvy, 1998. 352 p.

38. Fylypchuk O. M. Perechituiuchi Ioanna Skilitsiu: khto buv Sfeng - brat Volodimira Sviatogo? [Re-reading John Scylitzes: who was Sphengos, brother of St. Volodymyr?] Istorychna panorama: Zbirnik naukovikh statei Chernivets'kogo natsional'nogo universitetu. Spetsial'nist' "Istoriia" [Historical Panorama. Collection of the articles of Chernivtsi National University], 2009, vol. 8, pp. 58-70.

39. Filipchuk A. M. Rus' i Vizantiia v poslednie gody pravleniia Vasiliia II: Khrizokhir i ego voiny [Rus and Byzantium in the last years of Basil II: Chrusocheiros and his Warriors]. Colloquia Russica, 2015, vol. 5, pp. 55-70.

40. Khapaev V. V. Rol stratigov Khersona V osushchestvlenii vneshney politiki Vizantiyskoy imperii v pervoy polovine $\mathrm{X} v$. [The role of the strategoi of Cherson in the Implementation of Byzantine Foreign Policy of the first half of the $10^{\text {th }}$ Century]. Materialy po arkheologii i istorii antichnogo $i$ srednevekovogo Kryma [Materials on Archaeology and History of Ancient and Medieval Crimea], 2013, vol. 5, pp. 14-25.

41. Shakhmatov A. A. Razyskaniya o drevneishikh russkikh letopisnykh svodakh [Investigations for the Oldest Russian Chronicles]. Saint Petersburg, Tipografiya M. A. Aleksandrova Publ., 1908. 686 p.

42. Yanin V. L. Aktovye pechati Drevnei Rusi X$X V$ vv. T. 1. Pechati $X$-nachala XIII v. [Act's Seals of Ancient Rus of the $10^{\text {th }}-15^{\text {th }}$ Centuries. Vol. 1. The Seals of the $10^{\text {th }}-13^{\text {th }}$ Centuries]. Moscow, Nauka Publ., 1970.326 p.

43. Diaconu P. Les Petchénègues au Bas-Danube. Bucarest, Éditions de 1'Académie de la République socialiste de Roumanie, 1970. 158 p. (Bibliotheca historica Romaniae 27).

44. Felix W. Byzanz und die islamische Welt im früheren 11. Jahrhundert. Wien, Verlag der Österreichischen Akademie der Wissenschaften, 1981. $236 \mathrm{p}$.

45. Golden P. B. Studies on the Peoples and Cultures of the Eurasian Steppes. Bucureşti - Brăila, Editura Academiei Romane, Editura Istros a muzeului Brăilei, 2011.424 p.

46. Grierson P. Catalogue of the Byzantine Coins in the Dumbarton Oaks Collection and in the Whittemore Collection. Vol. 3. Part 1/2. Washington, DC, Dumbarton Oaks Research Library and Collection, 1973. X, 887 p., 70 pl.

47. Grierson P. Byzantine Coins. London, Methuen and Co., Berkeley, Los Angeles, University of California Press, 1982. XIII, 411 p. 
48. Guilland R. Les logothèthes. Etudes sur l'histoire administrative de l'Empire byzantine. Revue des études byzantines. 1971, vol. 29, p. 5-115.

49. Holmes C. Basil II and the Governance of Empire. New York, Oxford University Press, 2005. XIV, $625 \mathrm{p}$.

50. Thurn I., ed. Ioannis Scylitzae Synopsis Historiarum. Corpus fontium historiae byzantinae. Vol. 5. Berolini, Walter de Gruyter, 1973. LVI, 580 p.

51. Ivanišević V. Interpretation and Dating of the Folles of Basil II and Constantine VIII - the Class A2. Zbornik radova vizantoloshkog instituta [Journal of Byzantine Institute]. 1989, vol. 27/28, p. 19-42.

52. Flusin B., Cheynet J.-Cl., eds. Jean Scylitzès. Empereurs de Constantinople. Paris, Éditions P. Lethielleux, 2003. XXX, 467 p.

53. Worthley J., Flusin B., Cheynet J.-Cl., eds. John Skylitzes. A Synopsis of Byzantine History. Cambridge, Cambridge University Psess, 2010. XXXIII, 491 p.

54. Ljubarski J. N. Nikephoros Phokas in Byzantine Historical Writings. Byzantinoslavica, 1993, vol. 54, fasc. 2, pp. 245-253.

55. Morrisson C. Catalogue des monnaies byzantines de la Bibliothèque nationale. T. 2. Philippicus à Alexis III. Paris, Bibliothèque Nationale, 1970.844 p.

56. Jenkins R. J. H., Westerink L. G., eds. Nicholas I, Patriarch of Constantinople. Letters. Washington,
Dumbarton Oaks Center for Byzantine Studies, 1973. XXXVII, 631 p. (Corpus fontium historiae byzantinae. Vol. 6).

57. Panagiotakes N. Fragments of a Lost Eleventh CenturyByzantine Historical Work? Constantinides C. N., Panagiotakes N. M., Jeffreys E., Angelou A. D., eds. Philellēn: Studies in Honour of Robert Browning. Venice, Istituto ellenico di studi bizantini e postbizantini di Venezia, 1996, pp. 321-357.

58. Poppe A. O tytule wielkoksiążęcym na Rusi [On the title of Great Prince in Rus]. Przeglad Historyczny, 1984, vol. 75/3, pp. 423-439.

59. Seibt W. Johannes Skylitzes. Zur Person des Chronisten. Jahrbuch der Österreichischen Byzantinistik. 1976, vol. 25, pp. 81-85.

60. Shepard J. Byzantinorussica. Revue des études byzantines, 1975, vol. 33, p. 211-225.

61. Soloviev A. V. Archōn Rōsias. Byzantion, 1961, vol. 31, pp. 237-244.

62. Stephenson P. Review: Catherine Holmes, "Basil II and the Governance of Empire (976-1025)" (Oxford, 2005). Byzantinische Zeitschrift, 2007, vol. 100/1, pp. 218-223.

63. Talbot A.-M., Sullivan D. F., Dennis G. T., McGrath S., eds. The History of Leo the Deacon. Byzantine Military Expansion in the Tenth Century. Washington, DC, Dumbarton Oaks Research Library and Collection, 2005. XIX, $264 \mathrm{p}$.

\section{Information About the Author}

Alexandr A. Romensky, Candidate of Sciences (History), Researcher, Department of Byzantine History, State Museum-Preserve "Tauric Chersonesos", Drevnyaya St, 1, 299045 Sevastopol, Russian Federation, alexandrosromensky@gmail.com, https://orcid.org/0000-0003-0936-3740

\section{Информация об авторе}

Александр Александрович Роменский, кандидат исторических наук, научный сотрудник отдела византийской истории, Государственный музей-заповедник «Херсонес Таврический», ул. Древняя, 1, 299045 г. Севастополь, Российская Федерация, alexandrosromensky@gmail.com, https://orcid.org/0000-0003-0936-3740 